Article

\title{
Optimization of the Separation Efficiency of Buckwheat Seeds and Wild Radish Siliques in a Grader with Indented Pockets
}

\author{
Stanisław Konopka ${ }^{1, *} \mathbb{D}^{\mathbb{D}}$, Piotr Markowski ${ }^{1}{ }^{\oplus}$, Zdzisław Kaliniewicz $^{1}{ }^{\mathbb{D}}$, \\ Dariusz Jan Choszcz ${ }^{1} \mathbb{1}$, Adam Józef Lipiński ${ }^{1}$ and Elżbieta Kusińska ${ }^{2}$ \\ 1 Department of Heavy Duty Machines and Research Methodology, University of Warmia and Mazury in \\ Olsztyn, 10-719 Olsztyn, Poland; piotr.markowski@uwm.edu.pl (P.M.); \\ zdzislaw.kaliniewicz@uwm.edu.pl (Z.K.); choszczd@uwm.edu.pl (D.J.C.); \\ adam.lipinski@uwm.edu.pl (A.J.L.) \\ 2 Department of Engineering and Food Machinery, University of Life Sciences in Lublin, 20-950 Lublin, \\ Poland; elzbieta.kusinska@up.lublin.pl \\ * Correspondence: stanislaw.konopka@uwm.edu.pl; Tel.: +48-089-523-36-07
}

Received: 25 September 2018; Accepted: 19 October 2018; Published: 24 October 2018

\begin{abstract}
The separation parameters and indicators of separation efficiency of a mixture of two types of seeds in a grader equipped with five interchangeable cylinders with indented pockets of various depths were optimized. The analyzed mixture was composed of buckwheat seeds and wild radish siliques, which are difficult to separate. A self-made computer program based on genetic algorithms was developed for the needs of the study. The value of the optimized indicator of separation efficiency ( $\varepsilon=0.993)$, which is a product of partial indicators (buckwheat seed yield $\varepsilon_{1}$ and separation efficiency of wild radish siliques $\varepsilon_{2}$ ), was highest at the following operating parameters: Depth of indented pocket $s=2.9 \mathrm{~mm}$, kinematic index $k=0.25$, static load rating of a cylinder $q=0.1$, and inclination angle of the working edge of the trough $\alpha=12.0^{\circ}$.
\end{abstract}

Keywords: buckwheat seeds; wild radish siliques; grader; indented pocket; separation; optimization

\section{Introduction}

Buckwheat (Fagopyrum esculentum Moench) is a dicotyledonous crop and one of the 18 species of the genus Fagopyrum, which is grown mainly in the temperate climates of Europe and Asia [1,2]. Russia and China have the largest area dedicated to buckwheat production and the highest buckwheat yields. Other leading producers of buckwheat include Ukraine, France, Poland, Kazakhstan, USA, Brazil and Japan [3]. Buckwheat is cultivated mainly on low-quality soils, and it thrives on soils with a slightly acidic or neutral $\mathrm{pH}$. Its growth and development can be inhibited by environmental stressors such as drought, excessive soil moisture (due to prolonged rainfall), considerable fluctuations in temperature, and ground frost. For this reason, buckwheat is generally regarded as a crop with unstable yields [3-5]. Adverse weather and the absence of pollinating insects during flowering can also significantly inhibit seed setting $[6,7]$.

Buckwheat plants produce triangular grain-like nutlets referred to as grains or seeds. Buckwheat seeds contain readily available protein $(10-16 \%)$, starch $(60-84 \%)$, fat $(2-3 \%$, mostly healthy unsaturated fatty acids), vitamins (mostly B1, B2, P and PP), organic acids (malic and citric acid), minerals (iron, phosphorus, calcium, zinc, copper, boron, nickel, iodine, cobalt) and small amounts of sugars $[3,8,9]$. Buckwheat seeds and plants are abundant in flavonoids (including rutin) with antioxidant properties [3,10-12]. Buckwheat seeds are mainly processed into groats and flour for the production of pasta, pancakes, snack bars and bread [13]. Buckwheat is also the basic domestic 
resource for the production of gluten-free foods which are recommended in gastrointestinal disorders, in particular atherosclerosis and celiac disease [3,14-16].

In Europe, up to $15 \%$ of threshed buckwheat supplied to the commodity market, in particular buckwheat from organic farms, contains impurities, which are mostly wild radish siliques [17-20]. Seed purity is the main criterion for classifying a given batch of seeds as suitable for planting or for the production of groats, buckwheat flour, and gluten-free foods. The gluten content of $1 \mathrm{~kg}$ of seeds for the production of gluten-free foods cannot exceed $20 \mathrm{mg}$ [21]. These requirements are often difficult to meet in practice, they lead to considerable loss of seeds, and increase the cost of cleaning operations. These issues can be attributed to the fact that buckwheat seeds and impurities have similar aerodynamic and geometric properties, which are used in the traditional cleaning process [17,22,23]. For this reason, new machines and equipment for cleaning (sorting) seeds are designed mainly based on differences in the shape of the separated components. Seed mixtures are separated with the use of belt graders [24], cylinders with long indented pockets [25] and longitudinal grooves [17], grader screens with triangular openings [26], cylindrical groove separators [27], and bar separators [23].

One of the most interesting solutions for separating buckwheat seeds involves cylinders with short indented pockets [28,29], the parameters of which are adjusted to the specific shape of buckwheat seeds (Figure 1). Buckwheat seeds fall into one-sided pockets in the lower part of a rotating cylinder and are effectively lifted to the trough. Wild radish siliques have a different shape and they lose balance when the tilt angle of a rotating cylinder is small. Siliques are pushed across indented pockets below the working edge of the trough and they move along the cylinder to the waste hopper. A previous study [22] demonstrated that mixtures composed of buckwheat seeds and wild radish siliques are more effectively separated in cylinders with short indented pockets than in conventional graders. The results were used to develop regression models describing the influence of pocket depth, the cylinder's kinematic index, and the static load rating, as well as the inclination angle of the working edge of the trough on buckwheat seed yield, and the separation efficiency of wild radish siliques and the seed mixture. The author of the above study concluded that the indicators of separation efficiency and separation parameters, which were changed during laboratory tests in steps only, should be optimized in further research.

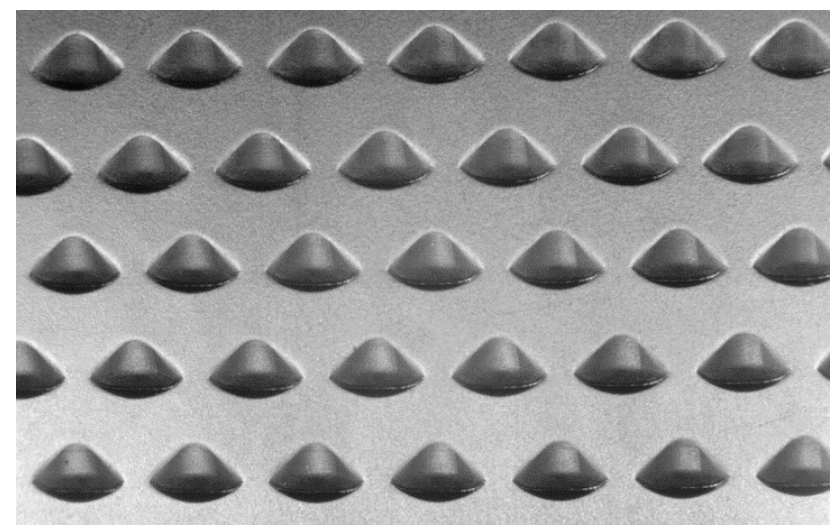

Figure 1. View of the internal surface of a cylinder with short pockets for separating buckwheat seeds.

The aim of this study was to optimize the separation parameters in a grader with indented pockets: Depth of indented pocket $(s)$, kinematic index $(k)$, static load rating of a cylinder $(q)$ and inclination angle of the working edge of the trough $(\alpha)$ in order to achieve the maximum values of indicators of separation efficiency: buckwheat seed yield $\left(\varepsilon_{1}\right)$, separation efficiency of wild radish siliques $\left(\varepsilon_{2}\right)$, and separation efficiency of the seed mixture $(\varepsilon)$. 


\section{Materials and Methods}

The separation efficiency of a seed mixture in a grader equipped with a cylinder with short indented pockets was analyzed [22,28,29].

The experimental material consisted of samples of buckwheat seeds cv. Emka and wild radish siliques (Table 1) which were separated manually from a mixture of harvested buckwheat seeds. Each sample consisted of $80 \%$ buckwheat seeds and $20 \%$ wild radish siliques. The analyzed samples were highly contaminated with wild radish siliques to minimize the risk of measurement errors [17].

Table 1. Selected physical parameters of the analyzed seed mixture (mean \pm standard deviation/minimum value-maximum value).

\begin{tabular}{ccc}
\hline \multirow{2}{*}{ Physical Parameter } & \multicolumn{2}{c}{ Species } \\
\cline { 2 - 3 } & Buckwheat Seeds & Wild Radish Siliques \\
\cline { 2 - 3 } Thickness $(\mathrm{mm})$ & $3.35 \pm 0.28$ & $3.61 \pm 0.65$ \\
& $2.61-4.14$ & $2.00-5.50$ \\
\hline \multirow{2}{*}{ Width $(\mathrm{mm})$} & $3.86 \pm 0.36$ & $3.82 \pm 0.65$ \\
& $2.99-4.84$ & $2.25-5.70$ \\
\hline \multirow{2}{*}{ Length $(\mathrm{mm})$} & $6.08 \pm 0.52$ & $5.88 \pm 1.02$ \\
& $4.89-7.15$ & $4.04-9.26$ \\
\hline \multirow{2}{*}{ Angle of external friction $\left(^{\circ}\right)$} & $29.4 \pm 4.97$ & $18.8 \pm 5.35$ \\
\hline \multirow{2}{*}{ 1000-seed weight $(\mathrm{g})$} & $17-43$ & $14.8 \pm 6.63$ \\
& $22.9 \pm 5.20$ & $4.5-39.5$ \\
\hline
\end{tabular}

The quality of the separation process of different seed samples was evaluated in the experimental test stand presented in Figure 2. The main component of the test stand was an interchangeable cylinder (1) with indented pockets rotating around its horizontal axis. The cylinder was equipped with a trough (7), the position of which was changed by rotating the trough around the cylinder's horizontal axis. The cylinder was powered by an electric motor (6) with a frequency converter (5) for controlling rotational speed. The separator was equipped with a studded roller feeder (2) from a multi-purpose seed roller. The feeder was powered by an electric motor (3) with a frequency converter (4) for controlling rotational speed (seed dose). Seed mixture components positioned deep inside the cylinder pockets were lifted and transported to the trough. The remaining components (with a shallow position) remained inside the cylinder and were transported to a separate container.

The test stand had the following parameters:

(a) Constant parameters:

$\begin{array}{ll}\text { cylinder length } & 480 \mathrm{~mm}, \\ \text { cylinder's internal diameter } & 240 \mathrm{~mm}, \\ \text { inclination angle of the cylinder's horizontal axis } & 2^{\circ}, \\ \text { inclination angle of an indented surface relative to its base } & 60^{\circ}, \\ \text { distance between the working edge of the trough and cylinder surface } & 6 \mathrm{~mm}, \\ \text { content of wild radish siliques in the seed mixture } & 20 \%,\end{array}$

(b) Variable parameters (working parameters):

- $\quad$ depth of indented pocket (s) - from 2.0 to $3.6 \mathrm{~mm}$, changed in steps of $0.4 \mathrm{~mm}$ (interchangeable cylinders),

- $\quad$ kinematic index ( $k$ - -from 0.15 to 0.45 , changed in steps of 0.1 ,

- $\quad$ static load rating of a cylinder $(q)$ - from 0.1 to 0.4 , changed in steps of 0.1 ,

- $\quad$ inclination angle of the working edge of the trough $(\alpha)$-from $10^{\circ}$ to $40^{\circ}$ relative to the cylinder's horizontal axis, changed in steps of $10^{\circ}$. 


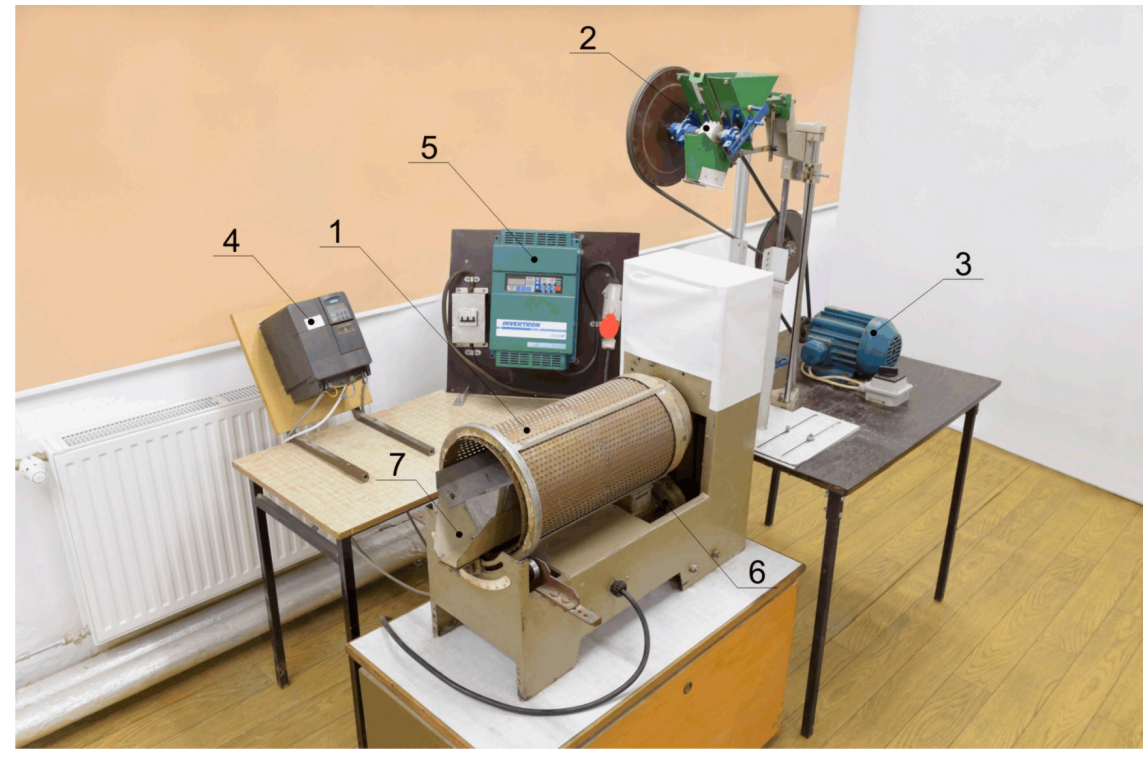

Figure 2. Experimental test stand: 1 -cylinder with indented pockets compatible with the Petkus K-292 laboratory grader, 2-feeder, 3-electric motor powering the feeder, 4-Siemens Micromaster 420 frequency converter, 5-Invertron GMI S13 frequency converter, 6-electric motor for powering the cylinder, 7-trough.

The quality of the separation process was evaluated based on three parameters: Buckwheat seed yield $\left(\varepsilon_{1}\right)$, separation efficiency of wild radish siliques $\left(\varepsilon_{2}\right)$, and separation efficiency of the seed mixture $(\varepsilon)$. The above indicators were determined based on the proportion of each component in the seed mixture and in the separated fractions [17,23,30-32]. The calculated indicators were expressed in proper fractions or in percentage. The variations in the above indicators ranged from 0 to $1(0 \div 100 \%)$, where smaller values were indicative of lower separation efficiency.

Dependent $\left(\varepsilon_{1}, \varepsilon_{2}, \varepsilon\right)$ and independent variables $(s, k, q, \alpha)$ were bound by the following functional correlations (1,2 and 3):

$$
\begin{aligned}
& \varepsilon_{1}=1.9327 s+0.5536 k-0.3117 s^{2}-1.7353 k^{2}-0.1841 q^{2}-0.0002 \alpha^{2}+0.0228 k \cdot \alpha-1.9883 \\
& \varepsilon_{2}=\left(25.6455 s+11.5237 k-0.1662 \alpha-6.1384 s^{2}+0.0013 \alpha^{2}-1.2531 s \cdot k+0.087 s \cdot \alpha+\right. \\
& -0.2895 k \cdot \alpha+70.8997) 10^{-2} \\
\varepsilon= & 2.1602 s+0.5865 k-0.0041 \alpha-0.3705 s^{2}-1.6628 k^{2}-0.1821 q^{2}-0.0002 \alpha^{2}+0.0014 s \cdot \alpha+ \\
+ & 0.0201 k \cdot \alpha-2.2018
\end{aligned}
$$

The analyzed working parameters were changed in steps, which necessitated the optimization of the indicators of separation efficiency and grader parameters.

A computer program based on genetic algorithms was designed for the needs of the study (Figure 3) to optimize non-linear, multi-modal and multiple-criteria mathematical models [33,34]. The optimization task was used to determine the values of working parameters $(s, k, q, \alpha)$ during the separation of buckwheat seeds and wild radish siliques, for which the objective function (F) describing the indicators of separation efficiency $\left(\varepsilon_{1}, \varepsilon_{2}, \varepsilon\right)$ fulfills the following equations:

$$
\begin{gathered}
\varepsilon_{1}=\mathrm{F}(s, k, q, \alpha) \rightarrow \text { maximum } \\
\varepsilon_{2}=\mathrm{F}(s, k, \alpha) \rightarrow \text { maximum } \\
\varepsilon=\mathrm{F}(s, k, q, \alpha) \rightarrow \text { maximum }
\end{gathered}
$$

The calculations involved the following operations: 
- The appropriate forms of the objective function (stochastic models) for optimization were found (Equations (1)-(3)).

- $\quad$ The search intervals (range of parameters) for the task were defined at $s<2.0 ; 3.6\rangle, k\langle 0.15 ; 0.45\rangle$, $q<0.1 ; 0.4>$ and $\alpha<10^{\circ} ; 40^{\circ}>$.

- $\quad$ The direction of the optimization process was selected.

- Constraint functions (the number of generations was limited to 200) were defined.

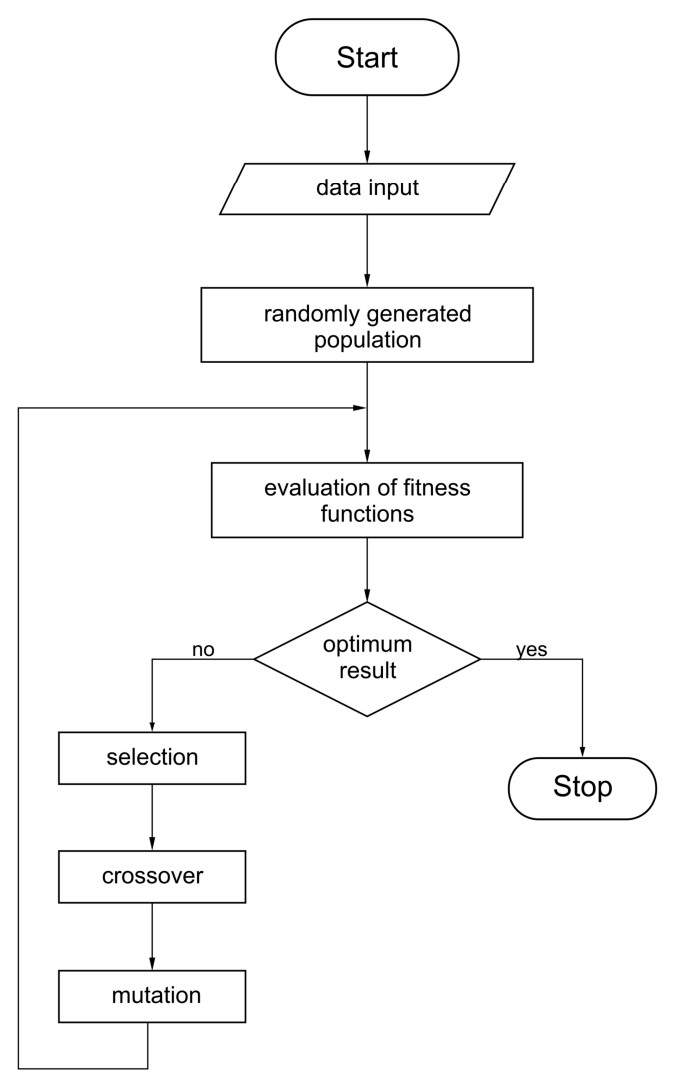

Figure 3. General diagram of the function and operating sequence of a genetic algorithm.

The parameters of the genetic algorithm (population size, probability values of genetic operators (selection, crossover, mutation) and termination condition) were determined based on analyses of preliminary tests. Successive iterations did not produce higher values of fitness functions.

\section{Results and Discussion}

The interface windows with the optimized values of the working parameters $(s, k, q, \alpha)$ and indicators of separation efficiency $\left(\varepsilon_{1}, \varepsilon_{2}, \varepsilon\right)$ of the seed mixture in a grader equipped with replaceable cylinders with indented pockets are presented in Figures 4-6. The search for the maximum values of the objective function revealed that wild radish siliques can be separated more effectively from the seed mixture based on the optimized values of the working parameters $(s, k, q, \alpha)$ in a grader equipped with a cylinder with indented pockets. The highest values of the analyzed indicators of separation efficiency were obtained for the following working parameters:

- $\quad \varepsilon_{1}=0.995$ at $s=3.10 \mathrm{~mm} ; k=0.255 ; q=0.1$ and $\alpha=14.6^{\circ}$.

- $\quad \varepsilon_{2}=0.997$ at $s=2.12 \mathrm{~mm} ; k=0.45$ and $\alpha=14.6^{\circ}$.

- $\quad \varepsilon=0.993$ at $s=2.93 \mathrm{~mm} ; k=0.254 ; q=0.1$ and $\alpha=12.0^{\circ}$. 


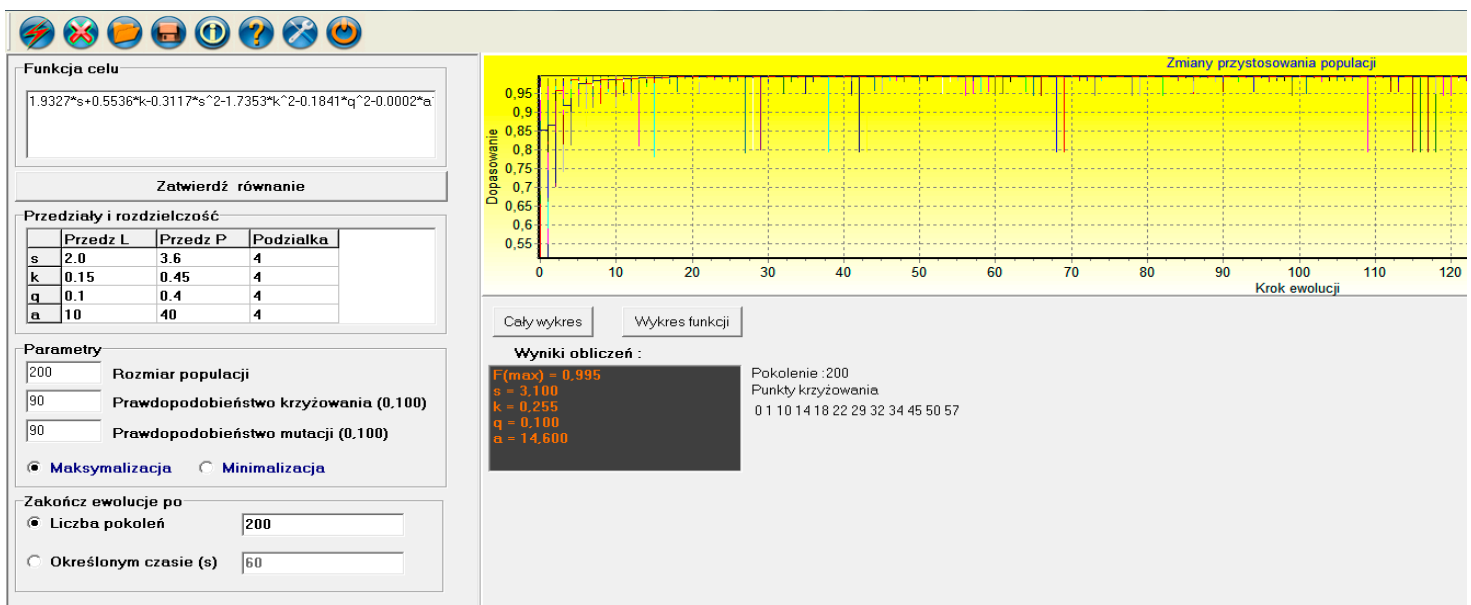

Figure 4. Graphic interface window with the optimized values of the working parameters $(s, k, q, \alpha)$ and buckwheat seed yield $\left(\varepsilon_{1}\right)$.

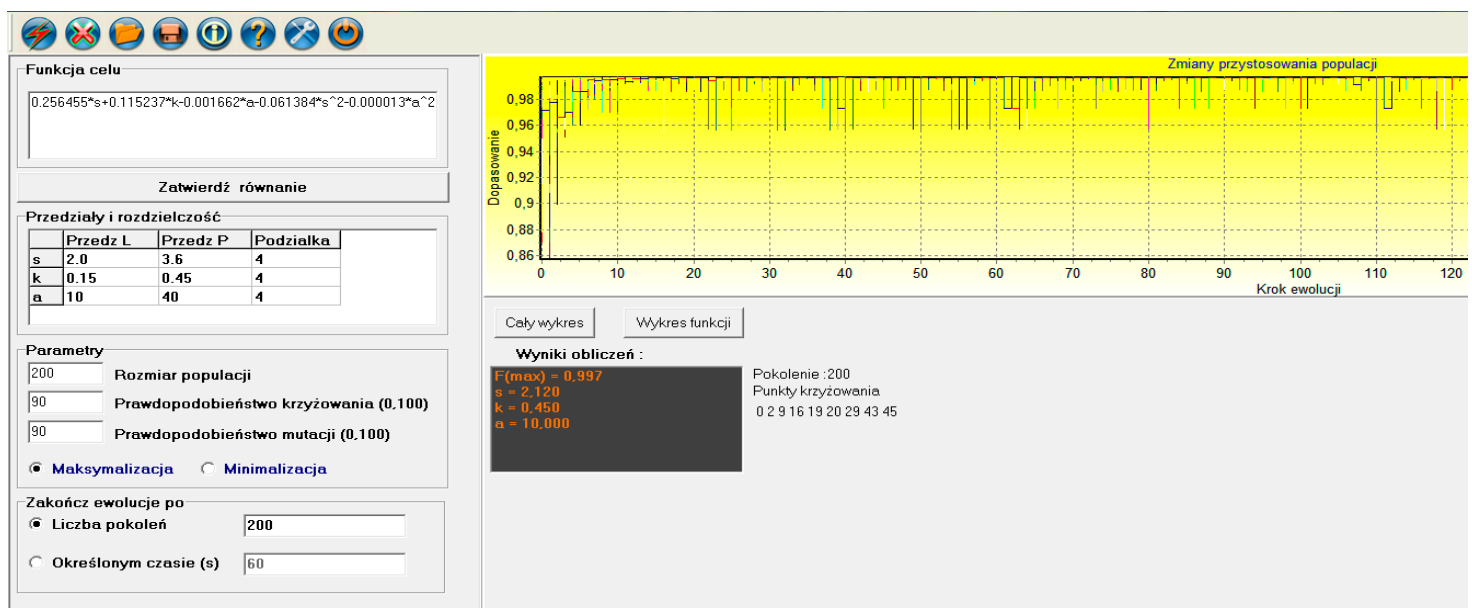

Figure 5. Graphic interface window with the optimized values of the working parameters $(s, k, q, \alpha)$ and the separation efficiency of wild radish siliques $\left(\varepsilon_{2}\right)$.

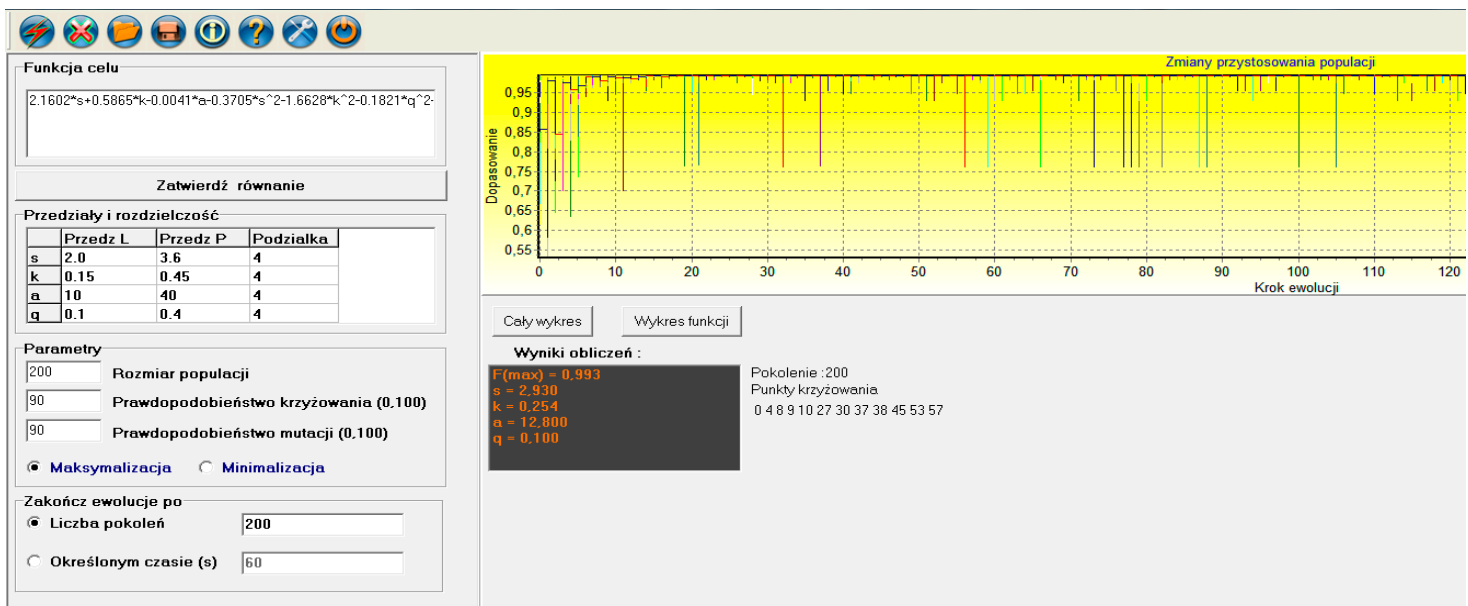

Figure 6. Graphic interface window with the optimized values of the working parameters $(s, k, q, \alpha)$ and the separation efficiency of the seed mixture $(\varepsilon)$.

The optimized indicators of separation efficiency were considerably higher than those determined experimentally. The above applies particularly to the separation efficiency of the seed mixture which peaked at $96 \%$ when buckwheat yield and the separation efficiency of wild radish siliques were 
determined at around $98 \%$ [22]. It should also be noted that the corresponding working parameters were not specified in the cited study. The optimal value of indicator $(\varepsilon)$ also exceeded the highest values noted in several devices for separating buckwheat seeds $[19,20,35,36]$.

A comparison of our results with other authors' findings revealed that the separation efficiency of wild radish siliques was somewhat higher $\left(\varepsilon_{2}=0.999\right)$ in the study by Konopka [23]. However, the above results were accompanied by a considerable (30\%) loss of buckwheat seeds.

\section{Conclusions}

The optimization of separation parameters and the indicators of separation efficiency of a mixture composed of buckwheat seeds $(80 \%)$ and wild radish siliques (20\%) in a grader equipped with cylinders with indented pockets demonstrated the usefulness of the designed computer program for optimizing multi-modal and multiple-criteria models describing seed processing operations. The proposed procedure supported the optimization of the working parameters, which were changed in steps during the laboratory experiment. A comparative analysis of experimentally derived and optimized indicators of separation efficiency supported the optimization of process parameters: buckwheat seed yield $\left(\varepsilon_{1}\right)$ and the separation efficiency of wild radish siliques $\left(\varepsilon_{2}\right)$ and the seed mixture $(\varepsilon)$. The highest values of partial indicators of separation efficiency $\left(\varepsilon_{1}\right.$ and $\left.\varepsilon_{2}\right)$ were achieved at different values of the working parameters. The above could imply that seed mixtures of this type should be separated in a two-stage process. However, the value of the optimized indicator of separation efficiency $(\varepsilon=0.993)$, which is a product of partial indicators $\left(\varepsilon_{1}, \varepsilon_{2}\right)$, and which determines the quality of the separation process, can be achieved at the following working parameters: $s=2.9 \mathrm{~mm}, k=0.25, q=0.1$ and $\alpha=12.0^{\circ}$.

Author Contributions: S.K. and D.J.C. conceived and carry out calculations; S.K., P.M. and Z.K. contributed to the literature study; S.K. and P.M. analyzed the results of calculations; A.J.L. and P.M. wrote the paper; S.K., D.J.C. and E.K. critically revised it.

Funding: This research received no external funding.

Conflicts of Interest: The authors declare no conflicts of interest.

\section{References}

1. Ohnishi, O. On the origin of cultivated buckwheat. In Proceedings of the 9th International Symposium on Buckwheat, Prague, Czech Republic, 18-22 August 2004; pp. 16-21.

2. Wang, L.; Yin, F. The geography distribution of wild buckwheat resources of Yunnan province of China. In Proceedings of the 9th International Symposium on Buckwheat, Prague, Czech Republic, 18-22 August 2004; pp. 265-270.

3. Jacquemart, A.L.; Cawoy, V.; Kinet, J.M.; Ledent, J.F.; Quinet, M. Is buckwheat (Fagopyrum esculentum Moench) still a valuable crop today? Eur. J. Plant Sci. Biotechnol. 2012, 6, 1-10.

4. Halbrecq, B.; Romedenne, P.; Ledent, J.F. Evolution of flowering, ripening and seed set in buckwheat (Fagopyrum esculentum Moench): Quantitative analysis. Eur. J. Agron. 2005, 23, 209-224. [CrossRef]

5. Japhet, W.; Zhou, D.; Zhang, H.; Zhang, H.; Yu, T. Evidence of phenotypic plasticity in the response of Fagopyrum esculentum to population density and sowing date. J. Plant Biol. 2009, 52, 303-311. [CrossRef]

6. Jacquemart, A.L.; Gillet, C.; Cawoy, V. Floral visitors and importance of honey bee on buckwheat (Fagopyrum esculentum Moench) in central Belgium. J. Hortic. Sci. Biotechnol. 2007, 82, 104-108. [CrossRef]

7. Taki, H.; Okabe, K.; Makino, S.; Yamaura, Y.; Sueyoshi, M. Contribution of small insects to pollination of common buckwheat, a distylous crop. Ann. Appl. Biol. 2009, 155, 121-129. [CrossRef]

8. Steadman, K.J.; Burgoon, M.S.; Lewis, B.A.; Edwardson, S.E. Obendorf, RL. Buckwheat seed milling fractions: Description, macronutrient composition and dietary fibre. J. Cereal Sci. 2001, 33, 271-278. [CrossRef]

9. Unal, H.; Izli, G.; Izli, N.; Asik, B.B. Comparison of some physical and chemical characteristics of buckwheat (Fagopyrum esculentum Moench) grains. CyTA-J. Food 2017, 15, 257-265. [CrossRef]

10. Jiang, P.; Burczynski, F.; Campbell, C.; Pierce, G.; Austria, J.A.; Briggs, C.J. Rutin and flavonoid contents in three buckwheat species Fagopyrum esculentum, F. tataricum, and F. homotropicum and their protective effects against lipid peroxidation. Food Res. Int. 2007, 40, 356-364. [CrossRef] 
11. Gulpinar, A.R.; Orhan, I.E.; Kan, A.; Senol, F.S.; Celik, S.A.; Kartal, M. Estimation of in vitro neuroprotective properties and quantification of rutin and fatty acids in buckwheat (Fagopyrum esculentum Moench) cultivated in Turkey. Food Res. Int. 2012, 46, 536-543. [CrossRef]

12. Lan-Sook, L.; Eun-Ji, C.; Chang-Hee, K.; Jung-Min, S.; Young-Boong, K.; Dong-Ho, S.; Hyun-Wook, C.; Yun-Sang, C.; Jun-Seok, K.; Jong-Dae, P. Contribution of flavonoids to the antioxidant properties of common and tartary buckwheat. J. Cereal Sci. 2016, 68, 181-186.

13. Levent, H.; Bilgiçli, N. Enrichment of gluten-free cakes with lupin (Lupinus albus L.) or buckwheat (Fagopyrum esculentum Moench) flours. Int. J. Food Sci. Nutr. 2011, 62, 725-728. [CrossRef] [PubMed]

14. Li, S.; Zhang, Q.H. Advances in the development of functional foods from buckwheat. Crit. Rev. Food Sci. 2001, 41, 451-464. [CrossRef] [PubMed]

15. Bonafaccia, G.; Marocchini, M.; Kref, I. Composition and technological properties of the flour and bran from common and tartary buckwheat. Food Chem. 2003, 80, 9-15. [CrossRef]

16. Christa, K.; Soral-Smietana, M. Buckwheat grains and buckwheat products-Nutritional and prophylactic value of their components-A review. Czech J. Food Sci. 2008, 26, 153-162. [CrossRef]

17. Rawa, T. Studia nad skutecznościa czyszczenia ziarna gryki [A study of the buckwheat grain cleaning effectivenss]. Acta Acad. Agric. Technol. Olst. Aedif. Mech. 1992, 22 (Suppl. A), 1-63.

18. Kwiatkowski, J.; Szczukowski, S.; Tworkowski, J. Production of buckwheat seeds on soil of a good wheat soil suitability complex. In Proceedings of the 9th International Symposium on Buckwheat, Prague, Czech Republic, 18-22 August 2004; pp. 475-480.

19. Pozeliene, A.; Lynikiene, S.; Sapailaite, I.; Sakalauskas, A. Utilization of strong electric field for special cleaning buckwheat seeds. Agron. Res. 2008, 6, 291-298.

20. Pozeliene, A.; Lynikiene, S.; Sapailaite, I. Use of electroseparator in improving the quality of ecological buckwheat seeds. Žemès Ūkio Mokslai 2010, 17, 56-59.

21. Codex Alimentarius Commission. Ad Hoc Working Group on the Revision of the Standard for Gluten-Free Foods. Available online: http:/ / eagri.cz/public/web/file/3535/al30_26e_1_.pdf (accessed on 23 October 2018).

22. Kaliniewicz, Z. Modelowanie tryjerów z wgłębieniami kieszonkowymi w aspekcie poprawy skuteczności czyszczenia nasion gryki [Modelling Trieurs with Pocket Pits in Aspect of Efficiency Improvement of Buckwheat Seeds Cleaning]. Ph.D. Thesis, Politechnika Warszawska, Wydział Budownictwa, Mechaniki i Petrochemii, Płock, Poland, 2000.

23. Konopka, S. Analiza procesu separacji nasion gryki przy wykorzystaniu prętowych powierzchni roboczych tryjerów [An analysis of buckweat seed separation process using trieur bar-type working surfaces]. Inżynieria Rolnicza 2006, 8, 123. (In Polish)

24. Wierzbicki, K.; Semczyszyn, M. Urządzenie do rozdzielania mieszaniny ziarnistej, zwłaszcza nasion gryki [A Device for Separating Seed Mixtures, in Particular Buckwheat Seeds]. Patent UP PRL No. P-137216, 30 November 1988. (In Polish)

25. Rawa, T. Cylinder do maszyny czyszczacej, zwłaszcza do czyszczenia ziarna gryki [Cleaning Cylinder in Particular for A Buckwheat Cleaning Machine]. Patent Application No. P-290419, 23 May 1991. (In Polish)

26. Rawa, T.; Semczyszyn, M. Oddzielacz nasion trójgraniastych, zwłaszcza nasion gryki [Separator of Three-sided Seeds, especially Buckwheat Seeds]. Patent UP PRL No. P-160088, 26 February 1993. (In Polish)

27. Konopka, S. Skuteczność czyszczenia gryki przeznaczonej do siewu i przetwórstwa [The Efficiency of Cleaning Buckwheat Seeds for Planting and Food Processing]. Ph.D. Thesis, Akademia Rolniczo-Techniczna, Olsztyn, Poland, 1995. (In Polish)

28. Kaliniewicz, Z.; Rawa, T. Analiza cech geometrycznych nasion gryki pod katem określenia kształtu i wymiarów wgłębień tryjera cylindrycznego [Analysis of geometrical characteristics of buckwheat seeds with respect to determining shape and dimensions of cylindrical trieur pits]. Problemy Inżynierii Rolniczej 2001, 1, 21-28. (In Polish)

29. Rawa, T.; Kaliniewicz, Z. Cylinder tryjera do czyszczenia nasion gryki [Trieur Cylinder for Cleaning Buckwheat Seeds]. Patent UP RP No. PL 187945, 30 November 2004. (In Polish)

30. Grochowicz, J. Maszyny do Czyszczenia i Sortowania Nasion [Seed Cleaning and Sorting Machines]; Wydawnictwo Akademii Rolniczej: Lublin, Poland, 1994. 
31. Kaliniewicz, Z.; Rawa, T. Analiza teoretyczna skuteczności rozdzielania mieszaniny nasion gryki i łuszczyn rzodkwi świrzepy w tryjerze z wgłębieniami kieszonkowymi [Theoretical analysis of the effectiveness of separating buckwheat seeds and wild radish siliques from their mixture in scooping area of a pocket trieur]. Problemy Inżynierii Rolniczej 2002, 4, 43-49. (In Polish)

32. Choszcz, D. Efektywność rozdzielania mieszaniny nasion rzepaku i przytulii czepnej w separatorze z taśmą petelkowa [Separation efficiency for mixture of rape and cleavers seeds in a separator with looped belt]. Inżynieria Rolnicza 2009, 7, 106. (In Polish)

33. Ahmed, S.G. Automatic generation of basis test paths using variable length genetic algorithm. Elsevier B.V. 2014, 114, 304-316.

34. Konopka, S.; Choszcz, D.J.; Markowski, P. Optimization of the separation parameters and indicators of separation efficiency of buckwheat seeds. Sustainability 2017, 9, 2134. [CrossRef]

35. Kaliniewicz, Z.; Konopka, S.; Rawa, T.; Wierzbicki, K. Propozycje nowych maszyn do czyszczenia ziarna gryki [Proposals of new machines to dry-cleaning of buckwheat grain]. Zeszyty Problemowe Postępów Nauk Rolniczych 2002, 486, 333-340. (In Polish)

36. Choszcz, D.; Konopka, S.; Wierzbicki, K. Wyniki badań wstępnych skuteczności czyszczenia nasion gryki $\mathrm{w}$ fotoelektrycznym separatorze [Preliminary test results of the efficiency of buckwheat seed cleaning in a photoelectric separator]. Inżynieria Rolnicza 2003, 7, 17-22. (In Polish)

(C) 2018 by the authors. Licensee MDPI, Basel, Switzerland. This article is an open access article distributed under the terms and conditions of the Creative Commons Attribution (CC BY) license (http:// creativecommons.org/licenses/by/4.0/). 